\title{
CORPORATE SOCIAL RESPONSIBILITY: MEASURING AND REPORTING THE EFFECTIVENESS OF COMMUNITY INVOLVEMENT ON THE BASIS OF THE LBG MODEL
}

\author{
Agnieszka Parlinska ${ }^{1}$, PhD; Ewa Stawicka ${ }^{2}, \mathrm{PhD}$ \\ 1, 2 Warsaw University of Life Sciences (WULS - SGGW)
}

\begin{abstract}
Corporate social responsibility is increasingly becoming the only way to sustainable development as well as the basis for competitiveness through factors such as the strengthening of brand reputation, attracting and keeping talented employees, an increase in efficiency, cost savings, meeting the expectations of society and creating new opportunities for business and contributing to economic growth. In connection with the necessity of the implementation of the sustainable development, business becomes aware of the executor of social objectives and business benefits. The objective of this paper is to introduce indicator the London Benchmarking Group (LBG) as a practical tool used in business to measure the costs and effects of social commitment of companies on the market. The analysis of the literature, simple statistical methods and case studies of several best practice applications of the LBG on the market were the research methods used in the paper. Special attention has been paid to the aspect of how the LBG model enables the evaluation of the costs and effects involved in companies actively participated in the model within years 2013-2016.
\end{abstract}

Key words: corporate social responsibility, indicator, social commitment, efficiency.

JEL code: O35, Q01

\section{Introduction}

Corporate social responsibility is a challenge in the framework of the implementation of the concept of sustainable development. In 2015, the UN General Assembly adopted 17 objectives of Sustainable Development Goals (SDG) for years 2015-2030 (Agenda 2030). On the one hand, sustainable development goals create the chances and opportunities and, on the other hand, become a necessity on the market. Practices of Corporate social responsibility (CSR) are seen now as one of the important elements in the implementation of the SDG and at the same time affecting the financial result. More and more entrepreneurs take action on behalf of their stakeholders and communities, treating them not as a cost but as an investment. At the same time, increasing awareness and understanding of the monitoring how the level of the companies' involvement in the community and environmental actions turn into profits (Waddock \& Graves, 1997).

One of the global standards for measuring corporate investments and philanthropy is the London Benchmarking Group (LBG Model). The LBG measuring frames are used by organizations worldwide to an effective measurement, reporting, and transfer of their social contributions and investments. The essence of the model is measuring the effectiveness of community action by reference results and effects to costs. The use of standardized tools allows comparing the effectiveness of its operations on the background of the industry or market.

The objective is to provide meter the LBG London Benchmarking Group as practical tools used in business to measure the costs and effects of social commitment of companies on the market. The methods used in the paper are: the analysis of a wide range of literature as well as several case studies of good practice application of the LBG on the market. The research focuses on the evaluation of best practices from a range of community investment in corporations in various sectors and countries. In the context of the challenges of global and sustainable development, good practices in the field of social and environmental aspects designate significant and measurable goals for the future. Data used in analysis were taken from the LBG's international network and provided the deepest set of benchmark data of companies actively participated in the LBG model within years 2013-2016. This depth of coverage helps to identify trends in community 
investment and to see how the companies that lead the field are taking on new approaches and measurement processes.

\section{Research results and discussion}

\section{The criteria for the effectiveness of CSR}

Corporate social responsibility is the positive impact that the company has on the surrounding community through its principal activity. This requires from them enforcement of law, ethical and international standards (Abou-El-Fouth, 2016). In turn, the European Commission's statement claims that CSR is a concept whereby companies voluntarily take account of social and environmental issues in their business and relations with stakeholders (Statement of the Commission..., 2011).

According to S. Sysko-Ryan, P. Roszkowska and A. Niedzwiecka, corporate social responsibility is an essential part of doing business in corporations that have enormous economic, technological, political, socio-cultural and ecological resources. This power is connected with responsibility for different aspects, such as:

- economy, which is above all control over the financial and technological resources, also it is related to the influence on the development and acquisition of new technologies,

- political manifests ensuring for company favourable legal regulations,

- marketing power, which is evidence of the socio-cultural changes effected by the operation of the entity.

More over ecological power is first of all resources that an enterprise has to protect the environment or ignore social expectations towards it (Sysko-Ryan, 2012).

According to the ISO 26000, "Guidance on social responsibility" CSR is a responsibility of the organization incurred by it in connection with the undertaken decisions and actions impacting on society and the environment. This responsibility should be ensured by the ethical and transparent conduct, which affects sustainable development, including health and prosperity of society, respects the expectations of stakeholders. At the same time, it should be in accordance with applicable law and consistent with the international standards (ISO 26000:2010).

The idea of sustainable development encourages more effective planning of the future and anticipating the consequences of their decisions and finding alternatives in case of failure. Corporate governance revolution has made the main theme of shareholders and boards interests are no longer only profits and their personal benefits. As a result, they began to ask what exactly a business is and how they should properly lead economic entity. The entities are trying to find a balance between the expectations of the Board of Directors and shareholders and other interested groups.

Nowadays the concept of CSR becomes of more strategic importance. From year to year, companies are interested in implementing into their business principles of social responsibility. Therefore, there is a need to measure the effectiveness and impact of the activities undertaken by them. Efficiency is often equated with the economy.

In the case of social responsibility, it can be defined as a situation when the obtained effects of a specific action exceed allocated costs to its implementation and the results of undertaken actions are described by the relation of the obtained effects to the expenditures incurred.

At the same time, what we believe to be effective, must be in some way related to the previously established objectives (Stawicka, 2017). 
Measuring the countable effects is potentially easy. It is more difficult to estimate the intangible benefits, such as social capital gain or social change. In this context, the tools to measure effectiveness are constantly developing, because it's hard to swap the effects in the material sphere on specific financial data (Figure 1).

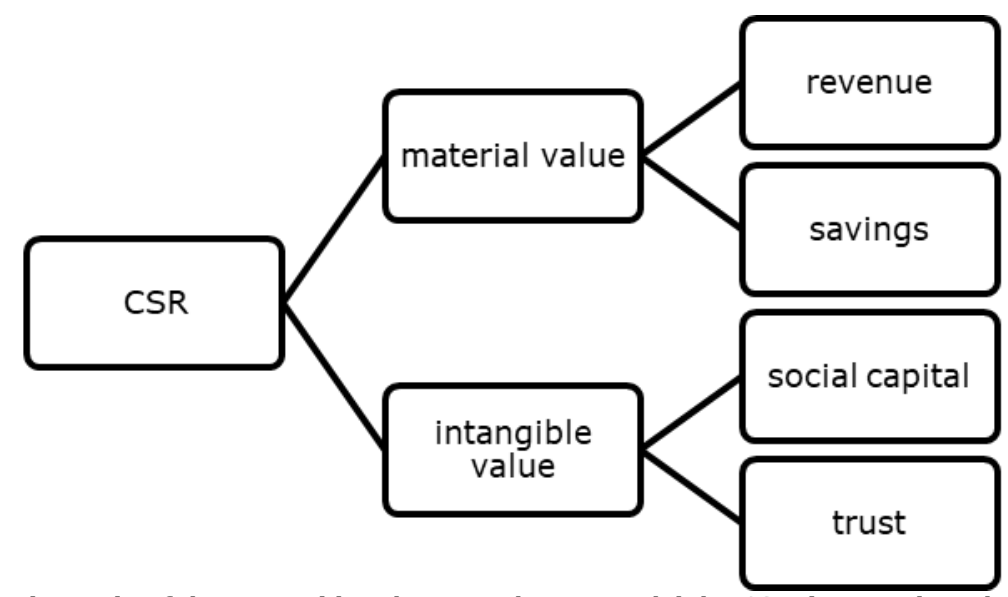

Source: FOB (2011) Mierzenie efektywnosci i wpływu społecznego działanCSR (Measuring The Effectiveness And Social Impact Of CSR Activities). Forum Odpowiedzialnego Biznesu, Warszawa. p. 4.

Fig. 1. The Effectiveness of CSR

The most popular and still developing measures of corporate social responsibility are: indicators of the Global Reporting Initiative (GRI), ISO 26000 and the London Benchmarking Group Model. However, the most commonly used in the world-standard management, measurement and reporting the effectiveness of social involvement is the LBG model.

The LBG model was formed in 1994 in the UK as the initiative of large companies that want to organize and mature to manage social programs and measure their effectiveness. It allows measuring not only the overall company's commitment, but also verifies what impact it will leave in long-term on the structure of the organization and its immediate environment. The LBG model is also a measure of efficiency and social commitment and the benefits of short-term and long-term impact from the perspective of business and societal benefit. In practical application, it allows also to measure in a holistic manner the incurred outlay by the company on social engagement, short term results and long term effects of this commitment.

\section{The LBG model in practice}

The LBG model allows calculation of the value of various resources involved in community activities, such as: provided products, working time of employees, volunteers, measuring the effectiveness of community action and the evaluation of short and long term benefits for the company of their implementation, improving the quality and transparency of reporting commitment society. Also it includes information about management and promotion cost related to the implementation of community action by the company, increasing the efficiency of the management of the different forms of social engagement of the company, the comparison - according to different criteria, community activities on the background market and industry. The LBG allows for accurate and comprehensive calculation of the value of the overall community involvement, and so the expression in monetary terms (in USA dollars or other currency), total costs/expenses incurred by the company in connection with the implementation of the community activities. Thus, not only the provided amounts in individual donations, but also the values of working time spent by employees on volunteer work or the cost of managing the different projects. The LBG model is also 
helpful in the process of evaluation system construction of community activities to measure the effectiveness of implemented activities in social as well business perspective.

The principle of the model and its main objective is to measure the effectiveness of community action by reference their effects and results to the incurred costs. This allows for comparison of the effectiveness of actions in relation to other companies or industries (Table 1).

The scope of the LBG model

\begin{tabular}{|c|c|c|}
\hline Input & Outputs & Impacts \\
\hline What is contributed? & What has been achieved? & $\begin{array}{l}\text { What changes we have } \\
\text { made? }\end{array}$ \\
\hline $\begin{array}{l}\text { The company resources used } \\
\text { in the framework of the } \\
\text { implementation of the } \\
\text { community activity; } \\
\text { - How? Cash, time, in-kind } \\
\text { management costs; } \\
\text { - Why? Investments, } \\
\text { donations, commercial } \\
\text { initiatives; } \\
\text { - Where? Location of activity; } \\
\text { - What? Area of social } \\
\text { problems (education, } \\
\text { health etc.). }\end{array}$ & $\begin{array}{l}\text { Additional measures obtained in the } \\
\text { framework of the activities carried out, } \\
\text { Number of persons supported; Benefits } \\
\text { and business achievement of the } \\
\text { commitment; } \\
\text { - Community outputs -the number of } \\
\text { people covered by the support; } \\
\text { - Additional benefits such as. support } \\
\text { obtained in addition to other entities; } \\
\text { - Business outputs -positive information } \\
\text { about the company in the media. }\end{array}$ & $\begin{array}{l}\text { Long-lasting social change } \\
\text { by the actions of the } \\
\text { company; } \\
\text { - Community impact- } \\
\text { social change - proof of } \\
\text { the change; } \\
\text { - Business impact - proof } \\
\text { of the long-term } \\
\text { benefits to the company } \\
\text { in connection with the } \\
\text { commitment. }\end{array}$ \\
\hline
\end{tabular}

Source: author's calculations based on Driving Community Investment. LBG Measuring Community Investment. 2016 Annual Review.

Practical application of the LBG model allows supporting the process of managing social programs. Key benefits of the LBG model can be considered: a full understanding of both the scale and value of social involvement; the possibility of a comprehensive assessment of the achieved results; better manage of social programmes; the ability to make better decisions regarding future social programs and improved communication on social involvement from both inside and outside the organization (Greszta, 2010).

The following tables contain results of the analysis across the LBG's international network and so provide the deepest set of benchmark data within years 2013-2016. This depth of coverage helps to better identify trends in social investment and see how the companies that lead the field are taking on new approaches and measurement processes. Among over the 130 thousand of countries where businesses in the LBG's network are making contribution more than $50 \%$ of companies are located in Europe and mainly in Great Britain. Until the year 2015, there can be observed the incising number of the companies in this network. However, from the 2016 the number of businesses actively participated in the benchmark was decreasing. In 2013 among companies participated in the LBG's annual benchmarking exercise a total contribution was 2.6 billion dollars, equivalent to an average contribution of 655 of dollars for each employee. The higher level of the total contribution was noticed in 2015 - 3.6 billion dollars. Companies are getting smarter about the management of their community programs. The LBG's rich input dataset shows how and to what extent things are changing. From the basics of how companies contribute cash as the lead, followed by in kind giving through to sectoral differences and the top social focus area: education and health. Moreover, rising emphasis on strategy with about $79 \%$ of community investment and commercial initiatives in the community can be observed in each of researched years (Table 2). 
Overview of organizations' investment in communities - The inputs

\begin{tabular}{|c|c|c|c|c|}
\hline Years & 2013 & 2014 & 2015 & 2016 \\
\hline \multicolumn{5}{|l|}{ Companies LBG } \\
\hline Number of companies & 109 & 111 & 173 & 168 \\
\hline \multicolumn{5}{|l|}{ Contribution } \\
\hline Total contribution (bn $\$$ ) & 2.6 & 2.5 & 3.6 & 3.3 \\
\hline Average contribution per employee $\$$ & 655 & 549 & 639 & 639 \\
\hline Average contribution as \% of pre-tax profit ( $\%)$ & $1.7 \%$ & $1.2 \%$ & $1.1 \%$ & $1.04 \%$ \\
\hline \multicolumn{5}{|c|}{ What members support? } \\
\hline Health & $24 \%$ & $36 \%$ & $22 \%$ & $19 \%$ \\
\hline Education and young people & $26 \%$ & $23 \%$ & $35 \%$ & $33 \%$ \\
\hline Others & $50 \%$ & $41 \%$ & $43 \%$ & $48 \%$ \\
\hline \multicolumn{5}{|c|}{ Why members contribute? } \\
\hline $\begin{array}{l}\text { Community investment and Commercial initiatives in the } \\
\text { community }\end{array}$ & $68 \%$ & $73 \%$ & $80 \%$ & $79 \%$ \\
\hline \multicolumn{5}{|c|}{ How members contribute? } \\
\hline Cash & $60 \%$ & $56 \%$ & $67 \%$ & $69 \%$ \\
\hline In-kind & $27 \%$ & $29 \%$ & $20 \%$ & $7 \%$ \\
\hline Time & $7 \%$ & $8 \%$ & $7 \%$ & $18 \%$ \\
\hline Management cost & $6 \%$ & $7 \%$ & $6 \%$ & $6 \%$ \\
\hline
\end{tabular}

Source: author's calculations based on LBG's International Report 2013, 2014, 2015, 2016

Measuring output means determining what happens as a result of community contributions. It's an opportunity to take the temperature of engagement and see some results. The numbers of people reached, the organizations supported or the additional funds brought to community programs from sources such as employees or customers are all markers by which companies in LBG can assess their progress. Within the years 2013-2015, decreasing number of beneficiaries and increasing number of employees involved and supported organization in the LBG network can be noticed (Table 3).

Table 3

Overview of what has been achieved? - The outputs

\begin{tabular}{|c|c|c|c|c|}
\hline Years & 2013 & 2014 & 2015 & 2016 \\
\hline \multicolumn{5}{|c|}{ Output } \\
\hline Total beneficiaries $(\mathrm{m})$ & 93 & 95 & 93 & 65 \\
\hline Supported organizations & 77000 & 186000 & 260000 & 203000 \\
\hline Employees involved & 525000 & 639000 & 600000 & 651000 \\
\hline
\end{tabular}

Source: author's calculations based on LBG's International Report 2013, 2014, 2015, 2016

Measuring impact is about understanding change. LBG enables and challenges companies to establish how they effect change in the people and the organizations that they help, as well as the employees that support their programs. As a result, the culture is changing, with more companies assessing their programs to establish where and how they are having a genuine impact (Table 4).

All over the world there can be noticed several best practices applications of the LBG on the market. In this paper, three case studies of good practice in this area from three different countries were analysed: Hemel Hempstead, project ABBOTT FUND and Orange companies.

The important initiative by British producer of soft drinks is based in Hemel Hempstead. It is listed on the London Stock Exchange and is a constituent of the FTSE 250 Index. It produces soft drinks under its own name. This program is global partnership between Fruit Shoot, Right to Play and international events organizer Tough Mudder delivers a series of Fruit Shoot Mini Mudder 
events for children across the UK, Ireland and the US. The events reinforce the importance of play and the power of teamwork. In addition, for every child that signs up, Fruit Shoot Mini Mudder makes a donation to Right to Play, a charity which transforms the lives of over one million disadvantaged children across Africa, the Middle East and Asia through the power of sport and play. Since its inception in February 2015, Britvic has contributed over $£ 15.000$ and leveraged nearly another $£ 3000$, benefitting 512 children facing adversity. Right to Play has put these funds towards activities which help children acquire important skills around teamwork and help build a brighter future for them and their communities. It also generated much positive PR with thousands of instore retailer displays and online likes on social media (www.britvic.com).

Overview of what changes we have made? - The impact

Table 4.

\begin{tabular}{|c|c|c|c|c|}
\hline Years & 2013 & 2014 & 2015 & 2016 \\
\hline \multicolumn{5}{|c|}{ How do people benefit? } \\
\hline Positive changes in behaviour & $44 \%$ & $66 \%$ & $41 \%$ & $31 \%$ \\
\hline Improved their well-being & $39 \%$ & $43 \%$ & $21 \%$ & \\
\hline Acquired new skills & $18 \%$ & $22 \%$ & $13 \%$ & \\
\hline \multicolumn{5}{|c|}{ How do organisations benefit? } \\
\hline $\begin{array}{l}\text { Improved existing/delivered new } \\
\text { services or products }\end{array}$ & $67 \%$ & $43 \%$ & $28 \%$ & $36 \%$ \\
\hline $\begin{array}{l}\text { Spend more time with or reach more } \\
\text { clients }\end{array}$ & $40 \%$ & $25 \%$ & $23 \%$ & \\
\hline Increase their profile & $38 \%$ & $31 \%$ & $30 \%$ & \\
\hline \multicolumn{5}{|c|}{ How do employee volunteers benefit? } \\
\hline Improved their job-related skills & $39 \%$ & $35 \%$ & $48 \%$ & $41 \%$ \\
\hline Changed behaviour/outlook & $60 \%$ & $62 \%$ & & $59 \%$ \\
\hline Improved life skills & $57 \%$ & $35 \%$ & & $58 \%$ \\
\hline
\end{tabular}

Source: author's calculations based on LBG's International Report 2013, 2014, 2015, 2016

The next example is project ABBOTT FUND from the USA. This program has supported 663 events to provide after-school science education for under-resourced communities. It delivers vital educational science opportunities, in an informal setting, encouraging young people to be more proficient in STEM - providing a path to a promising future. Abbott and the Abbott Fund contributed over $\$ 47 \mathrm{~m}$ in resources, including employee time and in-kind support to all STEM programs and exhibits, including Family Science and Operation Discovery. Over 260000 young students and their families have been involved with hands-on programming facilitated by Abbott scientists, engineering and other volunteers. The programs are replicable and sustainable, and participating teachers and parents have expressed increased ability and comfort in talking to students about STEM and STEM related careers with $97 \%$ of students reporting they were more interested in science after participating (www.abbott.com/contact.html).

Also Polish company Orange is committed to increasing the number of social programs, and hence more and more resources are spent on community activities. The Orange Foundation operates where there is a sharing of knowledge, competencies and positive energy with others. The volunteers are involved in the programs of the Foundation and a variety of other social initiatives. The Foundation offers them organizational, substantive and financial support. The company improved employee volunteering programs, conducting satisfaction surveys and employee expectations. The examples of their actions are:

- In 2013, implemented program "Safe Kids", which was allocated \$674 450, and Orange for libraries-5.6 mln; 
- "The Orange Labs" has gained popularity. The Labs are activities in which the initiators are working together? /have joined in? an initiative group, e.g. learning programming for children, musical workshops, intergenerational, jointly create board games, language courses, photography workshops, activities related to regional traditions and many others.

Initiatives are targeted at various audiences: children and youth, people with disabilities, young mothers, senior citizens. The Orange company systematically collects information from beneficiaries and local environments, to develop such projects that best match their needs.

Given the wide range of programs, communities with the LBG are able to show a comprehensive image of the involvement of companies. It can be seen, where financial support can be effectively supplemented with other elements, such as services that allow to achieve much better social results.

All of these good practices often are treated as a social innovation. Their effectiveness refers to the economic dimension, but very often has a dimension that returns after years in the form of social change. It specifies the effect of measures to change attitudes, awareness, changing lifestyles, commitment, improving the quality of life and the environment. Also it gives inspiration for other companies how and what for they can implement by? /applying? CSR and the LBD model.

\section{Conclusions, proposals, recommendations}

1) In the framework of the sustainable development concept complementation, there is increasing the importance of specific practices that improve the quality of life for people and environment. On the one hand, sustainable development goals make up the business chances and opportunities and, on the other hand, become a necessary on the market. Responsible actions have increasing importance as a social innovation is seen as element of building competitive advantage and at the same time affecting the financial result.

2) Currently, some barriers to sustainable development, climate change, demographic problems (the ageing of the population) can be surmounted only through innovation. Therefore, CSR is seen as a process and strategy for resolving the most difficult social problems. The entrepreneur shall take action on behalf of their stakeholders and communities, treating them not as a cost but as an investment. At the same time, increasing awareness and understanding of the monitoring of the extent to which the involvement of companies in the community and environmental actions translates into profits.

3) On the market, there can be observed a lack of universal tool or model that can be implemented in company in order to measure the effectiveness of the social commitment of companies and economic effect. One of the helpful tool that allows for the calculation of the value of the company's social commitment is the LBG model. It is based on standardized principles and tools to measure different forms of involvement (financial, in-kind, volunteer work and management costs). Therefore, there is a system that measures the effectiveness of social commitment in view of the short-term benefits and long-term impact from the point of view of the company, and benefits for society. This may mean that the LBG model can be considered not only as one of the effective tools to measure the commitment of the company. It can be also as a verifier of long-term commitment impact to one's own enterprise structures and direct neighbours. 


\section{Bibliography}

1. Abou-El-Fouth, H. (2016). Corporate Social Responsibility in Banks; What does it mean?. http://www.linkedin.com/pulse/corporate-social-responsibility-banks-what does-mean-abou-el-fotouh.html. Access: 02.02.2018.

2. Elkington, J. (2004). Enter The Triple Bottom Line. The Triple Bottom Line: Does It All Add Up, Volume 2004, 11(12), pp. 1-6.

3. Greszta, M. (2010). Pomiar efektywnosci. Zaangazowanie społeczne w odpowiedzialny biznes (Measurement of Effectiveness. Social Involvement in Responsible Business). Harvard Business Review Polska, No. 3(85), marzec, p. 4.

4. Waddock, S. A., Graves, S. B. (1997). The Corporate Social Performance- Financial Performance Link. Strategic Management Journal, 18(4), Volume 1997, pp. 303-319.

5. Agenda 2030. www.mr.gov.pl/strony/zadania/polityka-rozwoju-kraju/agenda-2030/. Access: 30.01.2018.

6. Komunikat Komisji do Parlamentu Europejskiego, Rady Europejskiego Komitetu Ekonomiczno-Społecznego i Komitetu Regionów. Odnowiona strategia UE na lata 2011-2014 dotyczaca społecznej odpowiedzialnosci przedsiebiorstw (Statement of the Commission to the European Parliament, the Council of the European Economic and Social Committee and the Committee of the Regions. A renewed EU strategy for 2011-2014 regarding corporate social responsibility) (2011). Bruksela. Access: 30.01.2018.

7. Stawicka, E. (2017). Sustainable Development and The Business Context of CSR Benefits o $n$ The Polish Market. Acta Scientiarum Polonorum. Oeconomia 2017, No. 16 (3), pp. 73-81.

8. Sysko-Romanczuk, S. , Roszkowska, P. , Niedzwiedzka, A. (2012). Odpowiedzialnosc biznesu. Teoria $i$ praktyka (Business Responsibility. Theory and Practice). Management and Business Administration No. 2/2012, pp. 26-40.

9. International Organization for Standarization, ISO 26000:2010, https://www.iso.org/iso-26000-socialresponsibility.html. Access: 30.01.2018.

10. FOB (2011). Mierzenie efektywnosci i wpływu społecznego działan CSR (Measuring The Effectiveness and Social Impact of CSR Activities). Forum Odpowiedzialnego Biznesu, Warszawa. p. 4.

11. ABC of the Main Instruments of Corporate Social Responsibility, European Commission. Office for Official Publications of the European Communities, Luxemburg 2004, pp. 35-37.

12. Raport CSR Orange Polska(CSR Orange Polska Report) (2015). http://www.raportcsropl.pl/wprowadzeniedo-raportu.html. Access: 14.12.2017.

13. The LBG Annual Review 2013. Local Input, Global Impact. Access: 20.12.2017.

14. The LBG Annual Review 2014. Maximum Impact. Access: 20.12.2017.

15. The LBG Annual Review 2015. Community Investment for a Changing World. Access: 20.12.2017.

16. The LBG Annual Review 2016. Driving Community Investment. Access: 20.12.2017. 